\title{
GEOLOGIA E LITOGEOQUIMICA DO COMPLEXO GRANÍTICO TRÊS CÓRREGOS NA REGIÃO DE BARRA DO CHAPÉU E RIBEIRÃO BRANCO, ESTADO DE SÃO PAULO
}

\author{
A.Gimenez Filho ${ }^{1}$, W.Teixeira ${ }^{2}$, M.C.H.Figueiredo (in memorian) ${ }^{2}$
}

A área do Complexo Granítico Três Córregos foi objeto, na década de 1980, de modelagens de evolução tectônica que consideravam as porções de rochas granitóides deformadas e/ou orientadas como pertencentes a um embasamento de idade arqueana. Por outro lado, diversos autores defendiam a linha de interpretação que mantinha tais rochas no complexo Três Córregos e consideravam-nas como formadas no Neoproterozóico.

Os resultados aqui apresentados vêm se alinhar com o modelo neoproterozóico, com os granitóides sendo formados em um ambiente de arco magmático, provavelmente de margem continental ativa.

A área estudada, de aproximadamente $900 \mathrm{~km}^{2}$, localiza-se na porção sudoeste do Estado de São Paulo (Fig. 1), junto ao limite com o Estado do Paraná, a sul da cidade de Itapeva (SP) e a norte de Curitiba (PR). Foi objeto de investigações de cunho geocronológico e litoquímico (Gimenez Filho, 1993).

A área estudada é dominada pelos granitóides do Complexo Três Córregos, por corpos da Suite Granítica Pós-Tectônica e por um corpo de augen gnaisses, considerado megaenclave nos granitóides Três Córregos. As unidades metassedimentares e/ou metavulcanossedimentares não foram objeto do estudo.

Os granitóides Três Córregos são constituidos, na área, predominantemente por hornblenda-biotita granitóides porfiróides e granitos leucocráticos microporfiríticos a equigranulares, além de granitóides orientados, que apresentam composições semelhantes às dos demais granitóides (ou seja, ora a hornblenda e biotita, ora leucocráticos microporfiríticos a equigranulares). Comumente encontram-se enclaves máficos de composição predominantemente diorítica potássica.

Foram realizadas análises químicas em 40 amostras para elementos maiores e traços, sendo 29 em litotipos considerados no Complexo Três Córregos (18 em granitos propriamente, 9 em enclaves e 2 em veios graníticos), 6 da Suíte Pós-Tectônica e 5 na área dos augen gnaisses ( 2 de augen gnaisses, 2 de enclaves e uma de veio granítico).

Destas amostras, 10 foram analisadas para elementos terras raras, sendo 7 dos granitóides Três Córregos (4 de granitóides e 3 de enclaves), uma da Suíte Pós-Tectônica e 2 na área dos augen gnaisses (uma de augen gnaisse e outra de enclave).

Os granitóides e enclaves máficos do Complexo Três Córregos parecem constituir uma seqüência cogenética que pode ser considerada básica-intermediária-ácida, cálcioalcalina de médio a alto-K, de granitóides tipo $\mathrm{I}$, gerados em ambiente compressivo. A distribuição de elementos incompativeis, incluindo os elementos Terras Raras, apresenta típicos

\footnotetext{
${ }^{1}$ Divisão de Geologia, Instituto de Pesquisas Tecnológicas do Estado de São Paulo. ${ }^{2}$ DGG, Instituto de Geociências, Universidade de São Paulo.
} 


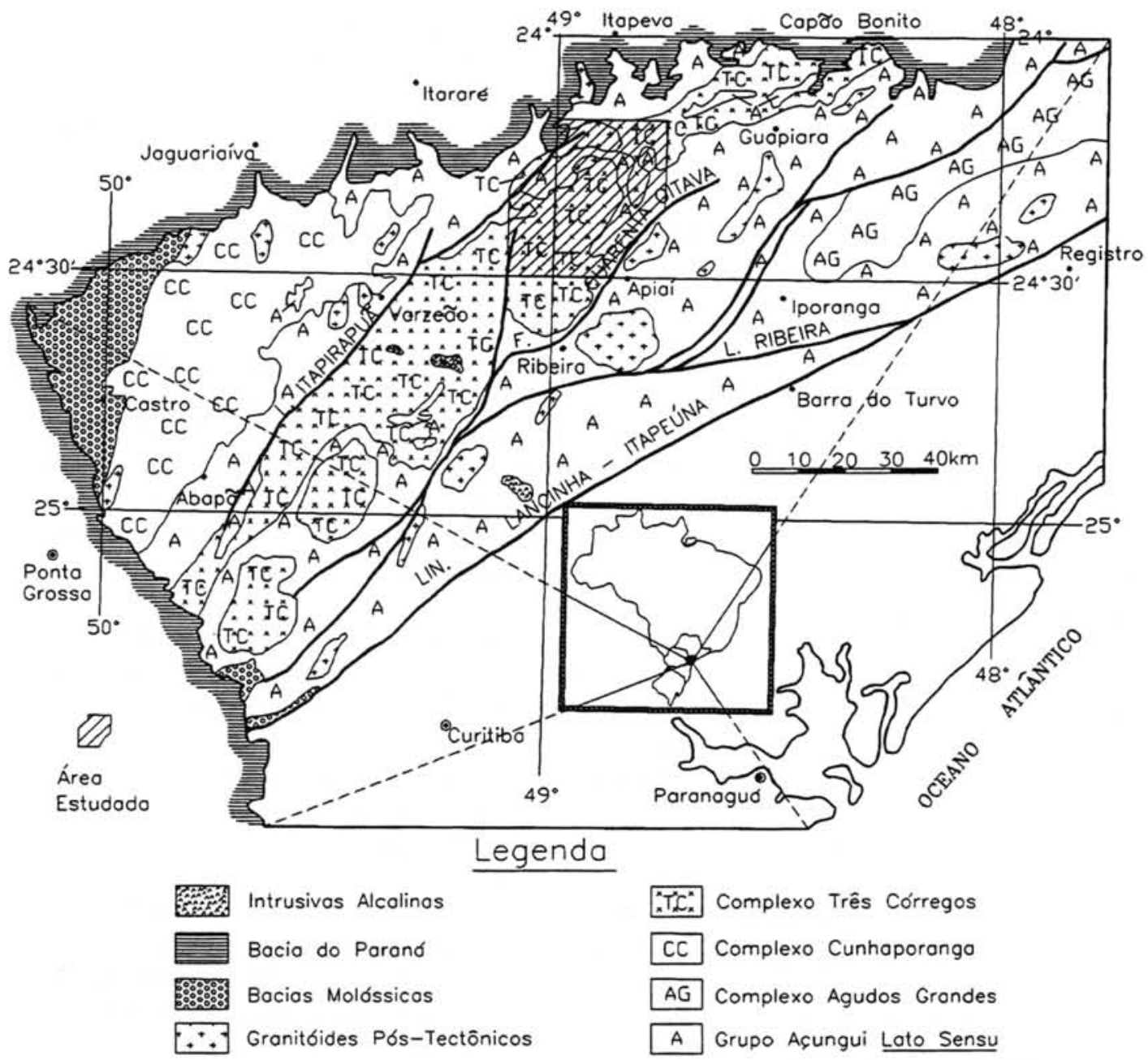

Figura 1 - Localização da área e esboço geológico regional.

componentes de zona de subducção. Os enclaves dioríticos potássicos podem corresponder a magmas derivados por fusão parcial de manto enriquecido, em cunha do manto acima de uma zona de subducção, com pelo menos alguma contaminação crustal durante sua evolução, armazenagem e colocação. Os granitóides intermediário-ácidos parecem estar relacionados aos $\mathrm{K}$-dioritos mas o mecanismo preciso deste relacionamento é ainda impreciso.

Este comportamento geoquímico é comparável ao de diversas suítes de arcos magmáticos, como as rochas da zona vulcânica central dos Andes e do batólito da costa do Peru (e.g. Pearce, 1983; Wilson, 1989) e de andesitos cálcio-alcalinos de arcos magmáticos modernos (Brown, 1982). Essas características parecem ser típicas de arcos vulcânicos maduros ou, mais provavelmente, de margem continental ativa. Adicionalmente, podem também ser encontradas em granitos caledonianos, de soerguimento pós-colisional ou alguns granitóides tardi-orogênicos.

Para os granitos da Suíte Pós-Tectônica os dados geoquímicos indicam tratarse de granitos fortemente diferenciados, formados por fusão crustal (tipo A), com campos coincidentes com o dos granitos intraplaca. 
Os augen gnaisses, contendo enclaves quartzo dioríticos a quartzomonzoníticos, têm composições distintas daquelas dos granitóides mais abundantes, e parecem, apesar do número muito reduzido de amostras analisadas, caracterizar uma sequeência cálcioalcalina de alto-Al.

\section{Referências Bibliográficas}

BROWN, G.C. (1982) Calc-alkaline intrusive rocks: their diversity, evolution and relation to volcanic arcs. In: THORPE, R.S. (Ed.) Andesites: orogenic andesites and related rocks. New York, Willey. p.437-461.

GIMENEZ FILHO, A. (1993) Evolução do complexo granitico Três Córregos a noroeste de Apiaí - SP. São Paulo, 118p. (Dissertação - Mestrado) - Instituto de Geociências, Universidade de São Paulo.

PEARCE, J.A. (1983) Role of the sub-continental lithosphere in magma genesis at active continental margins. In: HAWKESWORTH, C. J.; NORRY, M. J. (Eds.) Continental basalts and mantle xenoliths. Nantwich, Shiva, p.230-249.

WILSON, M. (1989) Igneous petrogenesis: a global tectonic approach. London, unwin hyman. 466p. 